\title{
UPAYA MENGOLAH LIMBAH SAMPAH MENJADI PELUANG SOCIAL ENTERPRISE EKONOMI KREATIF BAGI GENERASI-Z
}

\author{
Hernawati W Retno Wiratih ${ }^{1}$, Ilmi Dwiastuti ${ }^{2}$, Ikramina Larasati Hazrati Havidz ${ }^{3,}$ M Havidz \\ Aima $^{4}$, Shinta Amalina Hazrati Havidz ${ }^{5}$, Maya Puspita Dewi ${ }^{6}$ \\ ${ }^{1,2}$ President University, Jababeka \\ ${ }^{3,6}$ Universitas Esa Unggul, Jakarta \\ ${ }^{4}$ Universitas Mercu Buana, Jakarta \\ ${ }^{5}$ Bina Nusantara University, Jakarta.
}

hernawati_life@president.ac.id,ilmi.dwiastuti@president.ac.id, ikramina.larasati@esaunggul.ac.id, havidz.aima@mercubuana.ac.id, shinta.h@binus.ac.id, maya.puspita@esaunggul.ac.id

\begin{abstract}
Abstrak
The problem of waste in Indonesia has reached 175,000 tons/day which is equivalent to 64 million tons/year, which until now has been managed by being transported and dumped in the final processing site (TPA) because people still have the perception that waste is a waste material that is considered useless. The COVID-19 pandemic in 2020 has limited access to activities outside the home, ultimately changing the life-cycle of a people from offline to online. Generation $Z$ knows the mean of "sharing economy" and take the advantage of waste problems as challenges and opportunities that can create a generation of Social Entrepreneurs who create waste into products that have bargaining power and competitiveness in the creative economy market through social media or e-commerce platforms. Therefore, the study has main goals to change the behavior and mindset of Generation $Z$ to see waste dump as business opportunities for them. We utilized social media platform as the method to distribute the online flyers to collect the participants. The activity was held online through Zoom application. At the final sharing knowledge of zero waste, the study finds out that most of the participants excited with the idea of being an entrepreneur from the field they never have been thought before. Advance knowledge and insightful content delivered by the speakers lead to additional knowledge and self-development to the participants relate on the respective topic.
\end{abstract}

Kata Kunci : Ekonomi Kreatif, Gen Z, Limbah Sampah, Social Enterprise

\section{PENDAHULUAN}

Masalah limbah sampah di Jakarta dan kota-kota penyangga ibukota merupakan masalah yang selalu hangat untuk dibahas baik secara saintifik keilmuan maupun di lapangan untuk pengentasannya $\mathrm{Hal}$ ini karena Jakarta yang merupakan ibukota Negara Indonesia, juga, kota BODETABEK memiliki jumlah penduduk yang padat dan selalu mengalami pertambahan penduduk dari tahun ke tahun. Menteri Lingkungan Hidup dan Kehutanan (LHK) menyebutkan bahwa data timbunan sampah di Indonesia pada tahun 2020 mencapai 67,8 juta ton (Setiawan, 2021) dan diprediksi hal itu akan terus meningkat. Jika masalah ini dibiarkan, tempat pembuangan akhir (TPA) akan melebihi kapasitasnya dan tidak bisa mengatasi sampah-sampah tersebut. Widowati 
(2019) menyatakan bahwa jumlah yang ditimbulkan dari limbah sampah di Indonesia telah mencapai 175.000 ton/hari yang setara dengan 64 juta ton/tahun yang sampai saat ini pengelolaannya dilakukan dengan cara diangkut dan ditimbun di TPA sebanyak $69 \%$, dikubur $10 \%$, dikompos dan didaur ulang $7 \%$, dibakar $5 \%$, dan sisanya tidak terkelola $7 \%$. Dari data tersebut terlihat saat ini pengelolaan sampah masih terkonsentrasi di Tempat Pemrosesan Akhir (TPA) sampah tanpa melalui proses 3R (reduce, recycle, re-use).

Pada saat ini hampir semua negara berkembang (termasuk Indonesia) memiliki permasalahan dalam pengelolaan sampah (Dortman, 2015). Widowati (2019) mengatakan bahwa kesadaran masyarakat di Indonesia untuk mendaur ulang sampah tergolong rendah. Disisi lain Rahayu dan Sukmono (2013) mengatakan bahwa masyarakat menganggap sampah merupakan bahan buangan yang dianggap tidak berguna lagi tetapi perlu dikelola agar tidak membahayakan lingkungan dan kesehatan masyarakat. Akan tetapi pada kenyataannya, masyarakat Indonesia sendiri masih enggan dalam mengelola sampah baik sampah organik maupun sampah anorganik. Berdasarkan Badan Pusat Statistik (BPS, 2018), hanya 1,2\% rumah tangga yang mendaur ulang sampahnya. Sementara sekitar 66,8\% rumah tangga menangani sampah dengan cara dibakar. Padahal, asap yang ditimbulkan dari hasil pembakaran sampah organik bisa menimbulkan polusi udara dan mengganggu kesehatan. Sebanyak 32\% rumah tangga memilih cara lain untuk menangani sampah yang salah satunya dengan membuangnya ke sungai. Selain itu, sampah juga akan berdampak bagi lingkungan sosial ekonomi masyarakat. Sampah yang berserakan di lingkungan akan menimbulkan pemandangan yang buruk (Yunita, 2013).

Menteri Badan Usaha Milik Negara, Erick Thohir dalam Rapat Kerja Nasional Hipmi 2021 (CNN Indonesia, 6/3/2021), menyatakan bahwa rata-rata tingkat kewirausahaan di Indonesia tertinggal apabila dilihat dari negara tetangga ASEAN Malaysia dan Singapura, Thailand. Tingkat kewirausahaan masyarakat Indonesia hanya 3,47 persen. "Dapat dilihat bahwa tingkat rata-rata kewirausahaan Indonesia masih jauh tertinggal dari negara di Asia. Dapat kita lihat bagaimana
Thailand, Malaysia, dan Singapura sangat maju, rata-rata tingkat kewirausahaan di Singapura mencapai 8,76 persen, Malaysia sebesar 4,74 persen dan Thailand 4,26 persen." Sementara itu, tantangan lain yang mendadak harus dihadapi baik oleh Pemerintah maupun masyarakat luas termasuk pelaku bisnis adalah terjadinya pandemi COVID-19 di tahun 2020 yang telah membatasi akses untuk beraktivitas di luar rumah. Pandemi pada akhirnya mengubah perilaku konsumen. Berkurangnya aktivitas di luar rumah dan kegiatan di rumah saja membuat banyak masyarakat yang mengalihkan cara berbelanja kebutuhannya ke cara belanja online yang dinilai lebih memungkinkan untuk dilakukan.

Memanfaatkan masalah menjadi tantangan peluang yang dapat menguntungkan merupakan salah satu metode untuk melahirkan entrepreneur. Tumpukan "ton" sampah menuntut Gen Z dan masyarakat mengubah gaya hidup dengan mengolah limbah sampah, memanfaatkannya menjadi sumber ide bisnis baru sehingga dapat menjadi salah satu jalan keluarnya. Generasi Z (Gen-Z) merupakan generasi yang identik dengan teknologi dan informasi digital. Pada hiper-kustomisasi dikatakan bahwa Gen-Z mengkostumisasi segala hal yang berkaitan dengan diri mereka, termasuk informasi yang mereka butuhkan dan dirasakan akan mendatangkan manfaat ataupun keuntungan baginya. Generasi ini juga dikatakan sebagai Generasi Kolaboratif, generasi yang mengenal "ekonomi berbagi" yaitu generasi yang berpikiran memanfaatkan sumber daya yang ada dan siap untuk bermitra (kolaborasi) dengan mereka yang memiliki sumber daya tersebut.

Menurut Walgito (1999) dalam Alfiandra (2009), partisipasi masyarakat memiliki hubungan yang erat antara individu satu dengan individu yang lain atau sebaliknya, terdapat hubungan yang bersifat timbal balik dan saling mempengaruhi dan menguntungkan. Hubungan tersebut terdapat di antara individu dengan individu, individu dengan kelompok atau kelompok dengan kelompok. Dengan adanya permasalahan limbah sampah diatas diharapkan Generasi Z dapat mengolah limbah sampah untuk kemudian menjadi produk yang mempunyai daya tawar dan daya saing di pasar ekonomi kreatif melalui media social ataupun juga e-commers, sehingga keberlanjutan lingkungan 
hidup yang menjadi salah satu tujuan dari Sustainable Development Goals (SDGs) tercapai. Prinsip ekonomi dari ekonomi sirkular (Geissdoerfer et al., 2017) merupakan salah satu sistem ekonomi yang digunakan sebagai metode untuk mengatasi tantangan perubahan global seperti perubahan iklim, limbah, polusi, dan hilangnya keanekaragaman hayati. Dalam hal ini, Gen Z, dengan cara kerja milenialnya yang intens menyukai kolaborasi dapat menciptakan sentuhan unik dan perbedaan guna melakukan perubahan peningkatan ekonomi melalui ekonomi kreatifnya dan penciptaan pasar kerja baru.

\section{METODE}

Sasaran dari kegiatan ini adalah generasi, Gen Z, maka metode yang digunakan adalah yang diakrabi para Gen Z yaitu aktivitas sosialisasi dijalankan dengan menggunakan media sosialonline yang sedang sangat digemari para Gen Z, berkaitan Zero Waste-Mengolah Limbah Sampah Menjadi Peluang Ekonomi Kreatif dengan menggunakan media sosial Instagram (@zwsociety) yang dilaksanakan selama 14 hari (pada lampiran). Sosialisasi ini untuk memberikan informasi edukatif berkaitan beberapa langkah yang bermanfaat mengolah limbah sampah untuk menjadi memiliki "nilai jual" selain juga melakukan promosi produkproduk buatan anggota kelompok dari mahasiswa yang telah lebih dulu melakukannya (waste recycle).

Berikutnya adalah menyelenggarakan webinar tentang Zero Waste-Upaya Mengolah Limbah Sampah Menjadi Peluang Ekonomi Kreatif, serta informasi peluang bisnis yang dapat dihasilkan. Pelaksanaan webinar tersebut di atas bekerja sama dengan "Kertabumi Recycling Center" sebagai narasumber. Kertabumi Recycling Center merupakan organisasi non-pemerintah yang bergerak dalam bidang Social Entrepraises (kewirausahaan sosial) yang memperjuangan isu lingkungan terutama limbah sampah dan mempromosikan gaya hidup berkelanjutan, mereka mempromosikan produk-produk dari hasil pemanfaatan sampah dengan prinsip zero waste kepada masyarakat. Untuk lebih dapat menjangkau masyarakat MedSos (media social)-Generasi Z, maka dalam kesempatan ini juga bekerja sama dengan rekan media seperti IMTLI, IMTLI
Regional 2, sejutacita.id, Forest is Our Friend, BEM Environmental Engineering Universitas Presiden, dan AIESEC Universitas Presiden.

\section{HASIL DAN PEMBAHASAN}

Gen Z, apapun yang dilakukannya secara umum sangat berhubungan dengan dunia maya yang dikatakan sebagai "generasi digital" yang tech-savvy, web-savvy, appfriendly generation fasih teknologi (Hadion Wijoyo, at.all., 2020). Gen Z disebut juga iGeneration, generasi net atau generasi internet. Mereka memiliki kesamaan dengan generasi $\mathrm{Y}$, akan tetapi Gen $\mathrm{Z}$ mampu mengaplikasikan semua kegiatan yang dilakukannya dalam satu waktu yang bersamaan, seperti mendengarkan musik menggunakan headset, nge-tweet menggunakan ponsel, browsing dengan PC. Sejak kecil mereka, Gen Z, sudah mengenal teknologi dan akrab dengan gadget canggih yang secara tidak langsung berpengaruh terhadap pola perilaku mereka.

Pada dasarnya berbagai kebijakan telah disiapkan oleh pemerintah dalam mengurai masalah sampah. Antara lain dengan tentang PP No. 27 Tahun 2020 tentang Pengelolaan Sampah Spesifik, Peraturan Presiden No 97 Tahun 2017 tentang Kebijakan dan Strategi Nasional Pengelolaan Sampah Rumah Tangga dan Sampah Sejenis Sampah Rumah Tangga, dan Permen LHK No 75 Tahun 2019 tentang Peta Jalan Pengurangan Sampah oleh Produsen. Pengelolaan sampah seperti kumpul-angkut-buang yang disebut juga dengan pola linear justru membuktikan bahwa pola pikir pengelolaan sampah di Indonesia secara umum ketinggalan zaman. Pengelolaan sampah dengan paradigma baru dapat dilakukan dengan melakukan pengurangan dan penanganan sampah.

Pengurangan sampah dapat meliputi kegiatan $3 \mathrm{R}$ yaitu pembatasan (Reduce), penggunaan kembali (Reuse), dan pendaur ulang-an (Recycle). Sedangkan dalam pola kegiatannya dengan penanganan sampah melalui pemilahan, pengumpulan, pengangkutan, pengolahan, dan memproses akhir. Artinya, kita dituntut untuk dapat melakukan recycling agar bisa menjadi reuse yang bernilai jual secara ekonomi. Sehingga sampah yang dibuang adalah sampah yang benar-benar 
sudah tidak dapat lagi digunakan dan tidak lagi memiliki nilai ekonomi.

Dengan bobot materi yang tidak terlalu berat juga waktu yang singkat dipastikan bagi para peserta mampu untuk memahami semua bahan materi yang disampaikan oleh owner dari Kertabumi Recycling Center, yang telah bertahun menjalani Social Entrepreneurship, dengan mengadopsi dan menerapkan konsep ekonomi sirkular, yakni memanfaatkan nilai ekonomi sampah secara maksimal dengan menerapkan 3R, yakni mengurangi (reduce), menggunakan kembali (reuse) dan mendaur ulang sampah (recycle). Konsep ekonomi sirkular menjadi kunci pengelolaan sampah yang berkelanjutan.

Pelaksanaan Kegiatan Pengabdian Kepada Masyarakat (PKM) ini pembahasan materi didukung oleh Ikbal Alexander, MBA sebagai narasumber yang merupakan owner dari Kertabumi Recycling Center dengan pokok bahasan: 1) pengaruh sampah di Indonesia terhadap pemanasan global; 2) bencana alam yang terjadi akibat pemanasan global; 3) paradigma pengelolaan sampah; 4) teknik pengelolaan limbah sampah menjadi "cuan" pundi rupiah

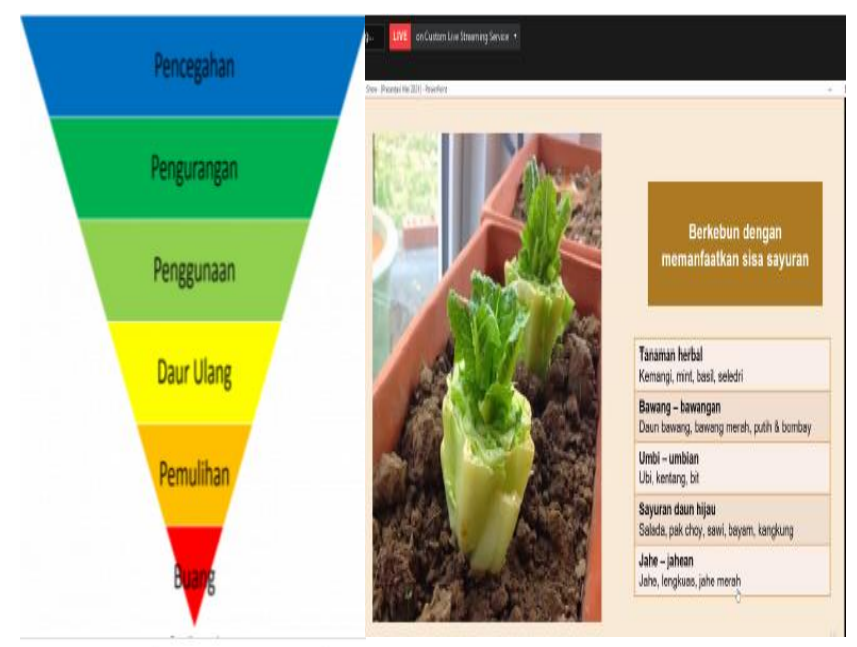

Gambar 1 ilustrasi Paradigma Baru

Pengelolaan limbah sampah (Sumber:

https://www.harianbhirawa.co.id/paradigmabaru-pengelolaan-sampah/)

Sangat dapat diharapkan Gen Z-para peserta webinar, sebagai "generasi digital yang appfriendly generation dan fasih teknologi dapat mengimplementasikannya "nilai ekonomi sampah" secara maksimal untuk menjadi "cuan". Diharapkan pula dengan pemberian materi tersebut dapat memberikan perubahan pola piker dan perubahan pelaku pada Gen Z untuk dapat melihat limbah sampah sebagai barang yang memiliki nilai ekonomi.Peserta kegiatan webinar sebanyak 231 orang dari berbagai daerah di Indonesia, diantaranya siswa Sekolah Menengah Atas (SMA), mahasiswa berbagai Universitas/Perguruan Tinggi di Indonesia, serta masyarakat umum. Kemampuan peserta dilihat dari penguasaan materi sangat baik dapat dilihat dari waktu yang singkat dalam penyampaian materi dan kemampuan para peserta yang tetap antusias dan semangat dalam mengajukan berbagai pertanyaan berkaitan sampah dan bisnisnya. Selain itu, bisa dilihat dari data peserta berdasarkan email dan yang telah mengisi formulir feedback webinar meliputi: 1) 184 peserta (80\%) merupakan mahasiswa dari berbagai Universitas/ Perguruan Tinggi di Indonesia; 2) 31 peserta (13\%) merupakan siswa sekolah SMA/SMK;3) 16 peserta (7\%) merupakan masyarakat umum antara lain guru SMA, guru SMK, karyawan Bappeda, karyawan DLH (Dinas Lingkungan Hidup).

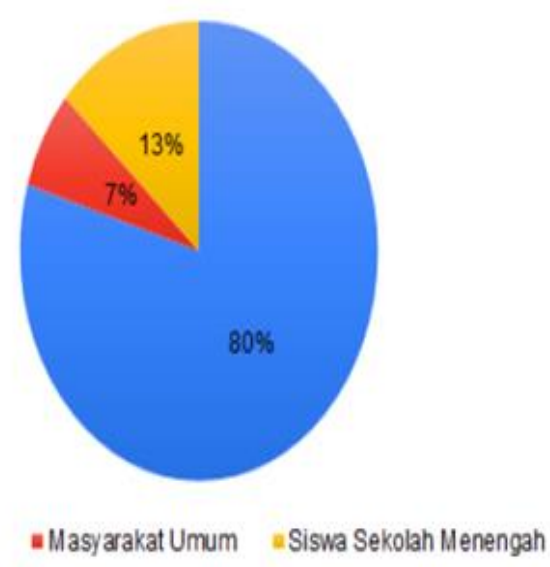

Gambar 2 Peserta Webinar (sumber data diolah peneliti

Pengelolaan limbah sampah menjadi "Cuan" pundi rupiah sama halnya dengan menciptakan peluang menjadi entrepreneur/wirausaha Mengidentifikasi dan 
membentuk peluang adalah inti dari domain kewirausahaan. 'At its core entrepreneurship revolves around the questions of why, when and how opportunities for the creation of goods and services in the future arise in an economyopportunity identification process' Memahami proses identifikasi peluang. Khususnya ide-ide yang mungkin diberkahi dengan potensi sosial dan ekonomi yang positif.

Seperti yang pernah dikatakan mantan Calon Presiden USA, Hubert H. Humphrey, yang dimuat dalam The Columbia World of Quotations (1996) dalam Kuratko (2016), bahwa Venturing Sosial merupakan 'Keuntungan dan moralitas adalah kombinasi yang sulit untuk dikalahkan'. Hal ini berkaitan bagi pengusaha yang didorong oleh keinginan untuk mencari solusi atas masalah lingkungan yaitu komoditas limbah sampah. Dan dapat dipastikan akan ada "number of money" uang (investasi dan benefit berupa keuntungan) yang tersedia. Disampaikan juga oleh narasumber, salah satu contoh dari produk inovatif yang dapat dihasilkan dari limbah elektronik adalah emas. Limbah elektronik termasuk ke dalam kategori limbah sampah, yang pada awalnya juga tidak mendapat perhatian dari individu karena dikira tidak memiliki nilai ekonomi. Namun, jika seorang individu dapat melihat limbah elektrronik tersebut sebagai nilai ekonomi, maka mereka dapat mempelajari limbah elektronik tersebut mulai dari proses hingga produksi limbah elektronik menjadi emas (Agincourt Resources, 2021).

Yayasan swasta dan individu swasta memberikan dana awal untuk rencana bisnis sosial yang menjanjikan. Banyak penyandang dana dan investor swasta mencari perusahaan yang memenuhi misi besar dengan cara yang mandiri. Kuratko Donald F. (2016) Social Enterprise (pengusaha sosial) bahkan lebih menantang daripada usaha bisnis biasa. Pengusaha sosial menghadapi tantangan ganda, mereka harus menemukan strategi yang efektif untuk mencapai perubahan sosial yang langgeng. Social Enterpreneur harus 'run the numbers" untuk benefit keuntungan sama kritisnya dengan usaha bisnis umumnya. Kewirausahaan sosial (social enterpreneurship) memadukan inovasi kewirausahaan terbaik dengan strategi mutakhir.

\section{KESIMPULAN}

Gen Z, yang dikatakan sebagai "generasi digital" apapun yang dilakukannya secara umum sangat berhubungan dengan dunia maya yang appfriendly. Secara umum kasat mata dipercaya untuk menjalankan peran sebagai Social Entrepreneurs yang dapat "run the numbers" guna mendapatkan benefit/keuntungan, dengan mengadopsi dan menerapkan konsep ekonomi sirkular,yakni memanfaatkan nilai ekonomi sampah secara maksimal dengan menggunakan kepiawaiannya pada digital (media social) untuk menjadikan limbah sampah menjadi "cuan." dengan cara kerja milenialnya yang intens menyukai kolaborasi dapat menciptakan sentuhan unik dan perbedaan guna melakukan perubahan peningkatan ekonomi melalui ekonomi kreatifnya dan penciptaan pangsa pasar kerja baru.

\section{REFERENSI}

Alfiandra, (2009). Kajian partisipasi masyarakat yang melakukan pengelolaan persampahan 3R di Kelurahan Ngaliyan dan Kalipancur Kota Semarang, Tesis, Universitas Diponegoro, Semarang. [terhubung berkala]. http://eprints.undip.ac.id/ 24266 / 1 / ALFIANDRA .pdf. [9 November 2013].

Agincourt Resources., (2021), Daur Ulang Limbah Elektronik yang Banyak Mengandung Emas,Jakarta:

https://www.agincourtresources.com/readagincourt/daur-ulang-limbah-barang-elektronikyang-banyak-mengandung-emas/

Dortmans B., (2015). Valorisation of organic waste-Effect of the feeding regime on process parameters in a continuous black soldier fly larvae composting system. Theses. Department of Energy and Technology, Swedish University of Agricultural Sciences, Swedish.

Hadion W., Irjus In., Yoyok C, Agus Leo H, Ruby S. (2020). GENERASI Z \& REVOLUSI INDUSTRI 4.0. CV. Pena Persada. Purwokerto Selatan, Kab. Banyumas. ISBN : 978-623-6504-864 
Democratic politician, vice-president, speech, 26 January 1967, Washington, DC, to international newspaper advertising executives, cited in The Columbia World of Quotations, 1996, http://www.bartleby.com/66/59/29659.html.

Kuratko Donald. F. et.all. (2016). Entrepreneurship: Theory/Proces/Practice, 4th edition. Cengage Leaming Australia Pty Llmlted . ISBN: 9780170352550

[KLHK] Kementerian Lingkungan Hidup dan Kehutanan, (2015). Rangkaian hari lingkungan hidup 2015-dialogpenanganan sampah plastik [terhubung berkala]. http://www.menlh.go.id [6 November 2015].

KLHK. (n.d.). Capaian Kinerja Pengelolaan Sampah. SIPSN. https://sipsn.menlhk.go.id/sipsn/

Kualitas Lingkungan Hidup. PPM "Pelatihan Pembuatan Kompos Limbah Organik dengan Dekomposer Lokal di Desa Binaan HIMA KIMIA FMIPA UNY. 13 Oktober 2013, Yogyakarta. Hal. 4-7

Rahayu, Dwi \& Sukmono, Yudi. (2013). Kajian Potensi Pemanfaatan Sampah Organik Pasarberdasarkan Karakteristiknya (Studi Kasus Pasar Segiri Kota Samarinda). Jurnal Sains \&Teknologi Lingkungan. 5. 77-90. 10.20885/jstl.vol5.iss2.art2.

Setiawan, A. (2021, February 23). Membenahi Tata Kelola Sampah Nasional. Indonesia.go.id.

Widowati, Hari (2019). Rumah Tangga yang Mendaur Ulang Sampah Hanya 1,2\%. https://databoks.katadata.co.id/datapublish/2019/11/ 01/komposisi-sampah-di-indonesia-didominasisampah-organik\#

Yunita, Isti. (2013). Mengenal Lebih Dekat Sampah Anorganik Sebagai Upaya Peningkatan Kualitas Lingkungan Hidup. PPM "Pelatihan Pembuatan Kompos Limbah Organik dengan Dekomposer Lokal di Desa Binaan HIMA KIMIA FMIPA UNY. 13 Oktober 2013, Yogyakarta. Hal. 47

\section{LAMPIRAN 1}

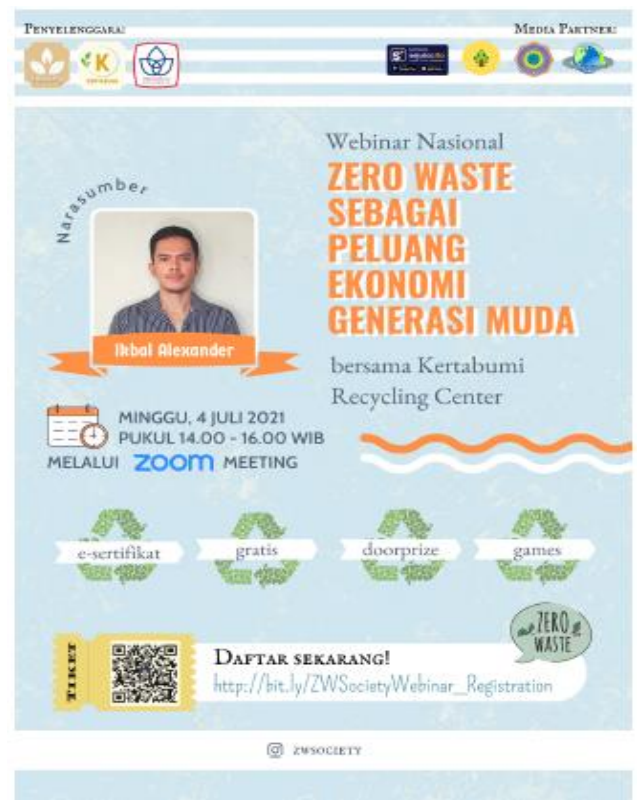

\section{LAMPIRAN 2}

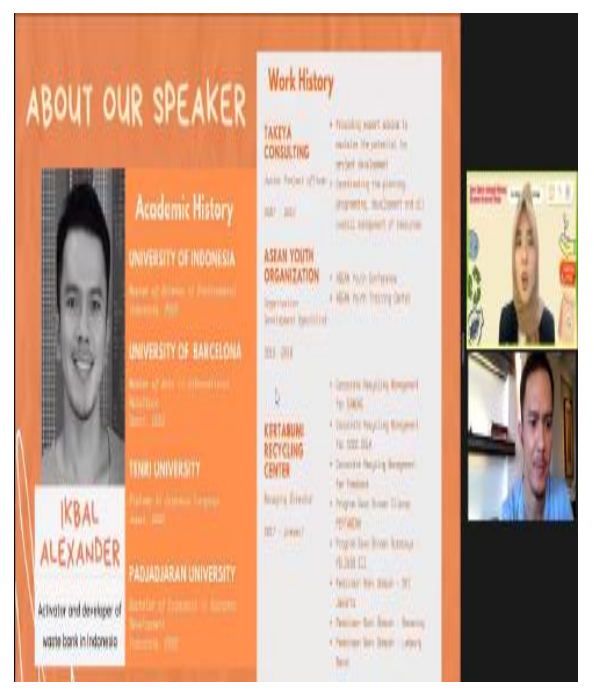




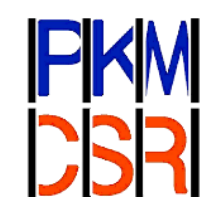

\section{LAMPIRAN 3}

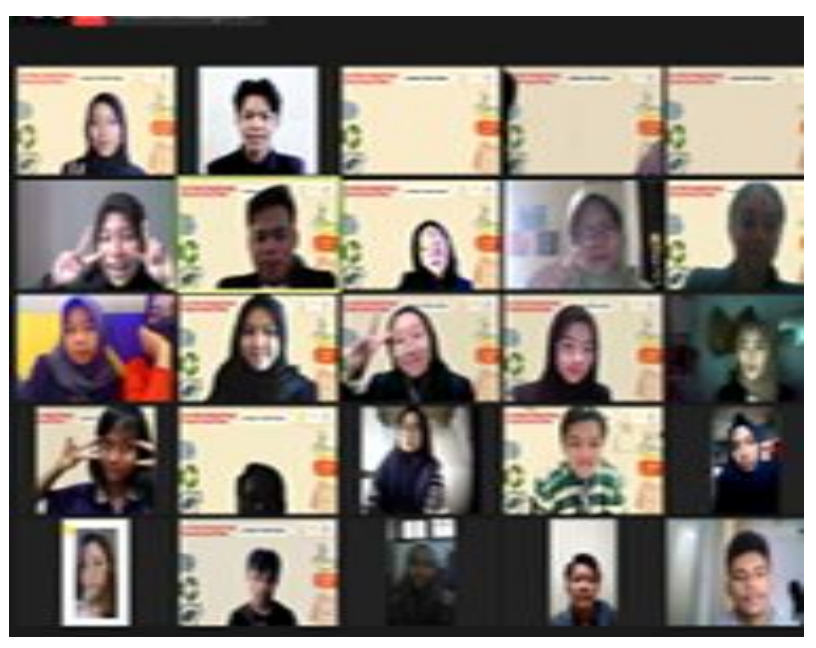

\section{LAMPIRAN 4}

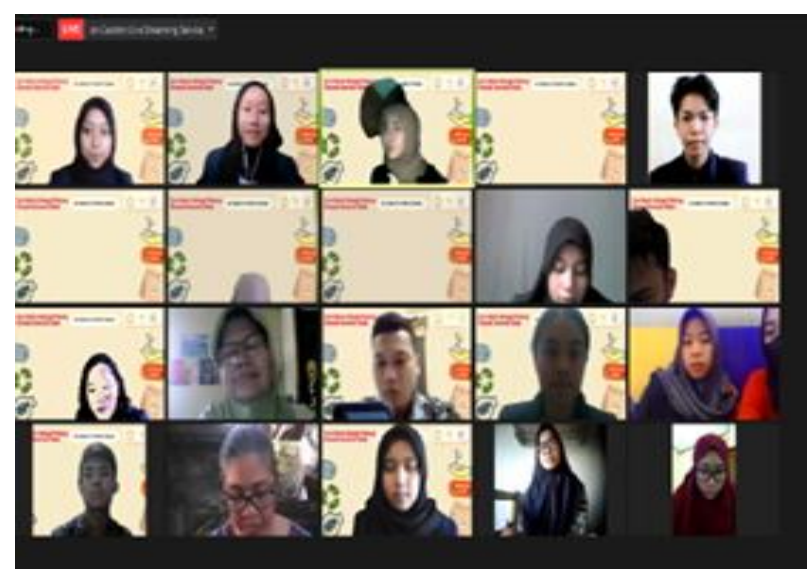

Ekonomi, Sosial, dan Budaya 1055 